Research Article

\title{
A Study to Evaluate and Assess the Prevalence and Risk Factors of Smoking among Young Males
}

\author{
Virinder Gill', Kavisha Kapoor Lal' ${ }^{2}$, Dhruvendra Lal ${ }^{3}$, Charanjit Singh' ${ }^{4}$
}

\begin{abstract}
${ }^{1}$ Assistant Professor, Department of Community Medicine, Gian Sagar, Hospital \& Medical College, Rajpura, Punjab, India. ${ }^{2}$ Senior Lecturer, Department of Periodontics, Himachal Dental College, Sunder Nagar, Himachal Pradesh, India.

${ }^{3}$ Assistant Professor, Department of Community Medicine, Dr B R Ambedkar State Institute of Medical Science, Mohali, Punjab, India.

${ }^{4}$ Senior Resident, Department of Paediatric and Preventive Dentistry, Desh Bhagat Dental College, Mandi Gobindgarh, India. DOI: https://doi.org/10.24321/2455.7048.202112
\end{abstract}

\section{I $\quad \mathbf{N} \quad \mathbf{F} \quad \mathbf{O}$}

\section{Corresponding Author:}

Dhruvendra Lal, Assistant Professor, Department of Community Medicine, Dr B R Ambedkar State Institute of Medical Science, Mohali, Punjab, India.

E-mail Id:

drdhruvlal@gmail.com

Orcid Id:

https://orcid.org/0000-0001-6973-9311

How to cite this article:

Gill V, Lal KK, Lal D, Singh C. A Study to Evaluate and Assess the Prevalence and Risk Factors of Smoking among Young Males. Epidem Int. 2021;6(2):14-19.

Date of Submission: 2021-05-28

Date of Acceptance: 2021-06-14

\section{$\begin{array}{llllllll}\mathbf{A} & \mathbf{B} & \mathbf{S} & \mathbf{T} & \mathbf{R} & \mathbf{A} & \mathbf{C} & \mathbf{T}\end{array}$}

Introduction: Smoking is known to be the single most preventable cause of death and disability. According to the WHO, 50\% of the total population are young adults who consume 6 trillion cigarettes per year. It has been found that smoking kills nearly 6 million people each year, leading to a total of 100 USD economic loss globally.

Methodology: A cross-sectional study was conducted on 807 participants, selected using probability proportionate to size (PPS) sampling method. The main objectives of the study were to find out the prevalence and to assess the risk factors in the young group of population.

Results: It was observed from our study that the overall prevalence of smoking came out to be $20.44 \%$, out of which, $15.73 \%$ were current smokers and $4.70 \%$ were ever smokers.

Conclusion: There is a need for establishing a smoking cessation clinic in every university which would help in motivating students to quit.

Keywords: Smoking, Prevalence, Risk Factors

\section{Introduction}

The pulmonary diseases due to smoking is a classical example of the modern-day epidemic. ${ }^{1}$ According to the WHO, $50 \%$ of the total population are young adults who consume 6 trillion cigarettes per year. ${ }^{2}$ It has been found that smoking kills nearly 6 million people each year, leading to a total of 100 USD economic loss globally. It has been estimated that tobacco may cause one billion deaths in the 21 st century, $80 \%$ of which may occur in developing countries like India. ${ }^{3}$

The use of tobacco can be seen in different parts of the world whether it is an economically developed or developing country. Vulnerable groups of young people have often been targeted by the tobacco industry, in both low and middle-income countries.

Smoking has even worst adverse effects in individuals with immunocompromised health conditions like ischemic heart disease, chronic obstructive disease etc. Chewing tobacco is a major risk factor for mortality globally. It kills more than 8 million people every year all over the world and the trend has risen in the last few years. ${ }^{4}$

More than 80,000 young people experiment with smoking and the current pattern shows a shift towards early adolescence. 5,6 Thus, tobacco use is one of the major causes of many health problems, but such health issues can be prevented by reducing the use of tobacco.

Smoking is the principal cause of mortality in India and it has been estimated that there are approximately 275 
million tobacco users, out of which, maximum people use it in smoking form. ${ }^{7}$

Factors associated with smoking among school children have been widely studied, but information regarding smoking amongst college students is very limited. Although there are many similarities between school children and college students, yet universities have a different social structure that influences the behaviour of students.

Previous studies have shown that peer pressure has a huge influence on the smoking behaviour among college students. ${ }^{8}$

According to the Surgeon General's report (USDHHS, 2000), smoking cessation is even more cost-effective than developing prevention and control programmes for diseases like cervical or breast cancer. ${ }^{9}$

Though primary prevention is the main objective of any tobacco control policy around the world, yet the treatment of tobacco dependence cannot be ignored. More emphasis should be on those who have recently started smoking like college students. The prevalence of smoking among young adults has a large variation. In India, 20 million students enter college annually. ${ }^{10}$ This gives an opportunity for public health specialists to organise smoking intervention programmes and reach a large population easily under one roof.

According to GYTS, tobacco smoking in young adults is significantly higher in people whose either parents are indulged in smoking. ${ }^{11}$ Studies also showed that apart from this, smoking by peers portends smoking in adolescents really strongly. ${ }^{12}$ In India, tobacco products are readily available at convenience stores that advertise at the point of sale.

Moreover, single stick sale of cigarettes makes them affordable, and lastly, indirect advertisements in mass media like movies and television are adding to the increased use of smoking by young people. ${ }^{13}$

This study was done to evaluate the prevalence and risk factors of smoking among the younger group of population.

\section{Aims and Objectives}

- To find out the prevalence of smoking in students (1830 years) studying in various colleges

- To assess the risk factors for smoking

\section{Material and Method}

This is a community-based, cross-sectional study in the rural part of Ludhiana. The study was approved by the research committee and ethical waiver was given as the study did not involve any interventions. This study was conducted over a period of three years from 2015 to 2018.

Study Population: All male young adults i.e. males between the ages of 18 and 30 years.

Inclusion Criteria: All males who were in the age group of 18-30 years and gave verbal consent to participate in this study were included in this study.

Exclusion Criteria: Females were excluded in this study owing to the social taboo. Males who were above 30 years or below 18 years of age and those who did not agree to participate were excluded from this study. Participants were ensured that anonymity shall be maintained throughout the course of this research project.

Interview method was used for data collection from the participants using a pre-designed questionnaire. Local language was also used to explain the participants for a better understanding of the questions.

Literature review revealed that the prevalence of smoking among young adults in India is $14 \%$ among males according to the WHO report on the Global epidemic 2013. ${ }^{2}$ The sample size was calculated by presuming the prevalence of smoking to be $14 \%$ (as obtained in the pre-test). Assuming this prevalence with a relative error of $20 \%$ at a level of significance of $95 \%$, the sample size was calculated.

The equation used for calculating sample size is as follows:

$n=Z^{2} P(1-P) / e^{2}$

Where,

$Z$ = level of confidence $-95 \%$ (1.96),

$\mathrm{P}=$ prevalence of smoking, and

$\mathrm{e}=$ margin of error

The sample size came out to be 756 .

\section{Sampling Technique}

House to house visits were conducted in which every male who was more than 18 years, but less than 30 years and gave consent was included in this study. All houses of the region were covered and a total of 807 participants were selected.

Study Tool: A semi-structured interview schedule was designed and utilised to collect data from the participants. The tool was pretested and modified accordingly.

\section{Definitions of the Dependent Variables}

Ever Smoker: People who had not smoked/chewed tobacco during the 30 days before the survey but had used it earlier were considered as ever smokers.

Current User: People who had smoked/ chewed tobacco minimum once during the 30 days before the survey were considered as current users.

Brief advice was given to help the participants understand the risk of tobacco use, benefits of quitting, and to motivate them to make a quit attempt. 


\section{Data Analysis}

SPSS Version 20 software was used to assess and evaluate the prevalence and risk factors for smoking and appropriate statistical tests were applied for the analysis of quantitative and qualitative data collected from the study.

\section{Results}

Table 1 depicts the age distribution of the study population. Only 807 participants were included in this study. It was observed that majority $(50.1 \%)$ of the population in the study belonged to the age group of 18 to 20 years, followed

Table I.Agewise Distribution of Study Population

\begin{tabular}{|c|c|c|}
\hline Age (years) & Frequency & Percentage \\
\hline $18-20$ & 404 & 50.1 \\
\hline $21-23$ & 150 & 18.6 \\
\hline $24-26$ & 158 & 19.6 \\
\hline $27-30$ & 95 & 11.8 \\
\hline Total & 807 & 100 \\
\hline
\end{tabular}

by $19.6 \%$ in the age group of 24 to 26 years. The percentages of the study population in the age groups $21-23$ years and $27-30$ years were $18.6 \%$ and $11.8 \%$ respectively.

Table 2 depicts the socioeconomic status of the study population according to the modified BG Prasad

Table 2.Socioeconomic Status of Study Population

\begin{tabular}{|c|c|c|}
\hline Socioeconomic Status & Number & Percentage \\
\hline Upper class & 225 & 27.9 \\
\hline Upper-middle class & 144 & 17.8 \\
\hline Middle class & 302 & 37.4 \\
\hline Lower-middle class & 120 & 14.9 \\
\hline Lower class & 15 & 1.8 \\
\hline Total & 807 & 100.0 \\
\hline
\end{tabular}

classification. It was noted from the table that majority (37.4\%) of the participants belonged to the middle class, followed by $27.9 \%$ from the upper class. Only $1.8 \%$ belonged to the lower class.

Table 3 depicts the prevalence of smoking according to age and category of smoking. Smokers were classified into current and ever smokers according to the WHO definition. It was observed from the below Table 3 that the overall prevalence of smoking came out to be $20.44 \%$, out of which $15.73 \%$ were current smokers and $4.70 \%$ were ever smokers.

Majority (24.21\%) of the current smokers were $27-30$ years old followed by $24-26$ years (18.98\%) and $21-23$ years (17.33\%). Only $11.8 \%$ of the current smokers were $18-20$ years old. The number of current smokers was increasing with age.

The number of ever smokers was the least $(2.9 \%)$ in the

Table 3.Agewise Prevalence of Smoking

\begin{tabular}{|c|c|c|c|c|}
\hline $\begin{array}{c}\text { Age } \\
\text { (years) }\end{array}$ & $\begin{array}{c}\text { Current } \\
\text { smokers } \\
\mathbf{n}(\%)\end{array}$ & $\begin{array}{c}\text { Ever } \\
\text { smokers } \\
\mathbf{n}(\%)\end{array}$ & $\begin{array}{c}\text { Non- } \\
\text { smokers } \\
\mathbf{n}(\%)\end{array}$ & $\begin{array}{c}\text { Total } \\
\mathbf{n}(\%)\end{array}$ \\
\hline $18-20$ & $48(11.88)$ & $12(2.97)$ & $\begin{array}{c}344 \\
(85.14)\end{array}$ & $\begin{array}{c}404 \\
(100)\end{array}$ \\
\hline $21-23$ & $26(17.33)$ & $09(9.00)$ & $\begin{array}{c}115 \\
(76.66)\end{array}$ & $\begin{array}{c}150 \\
(100)\end{array}$ \\
\hline $24-26$ & $30(18.98)$ & $09(5.6)$ & $\begin{array}{c}119 \\
(75.31)\end{array}$ & $\begin{array}{c}158 \\
(100)\end{array}$ \\
\hline $27-30$ & $23(24.21)$ & $08(8.42)$ & $64(67.36)$ & $\begin{array}{c}95 \\
(100)\end{array}$ \\
\hline Total & $127(15.73)$ & $38(4.70)$ & $\begin{array}{c}642 \\
(79.55)\end{array}$ & $\begin{array}{c}807 \\
(100)\end{array}$ \\
\hline
\end{tabular}

$\left(\chi^{2}=19.6, d f=6, p=0.003\right)$

Table 4.Association Between Socioeconomic Status and Smoking in the Study Population

\begin{tabular}{|c|c|c|c|}
\hline $\begin{array}{l}\text { Socioeconomic } \\
\text { Status }\end{array}$ & $\begin{array}{c}\text { Current } \\
\text { Smokers } \\
\text { n (\%) }\end{array}$ & $\begin{array}{c}\text { Non- } \\
\text { smokers } \\
\text { n (\%) }\end{array}$ & $\begin{array}{l}\text { Total } \\
\text { n (\%) }\end{array}$ \\
\hline Upper class & 30 (13.33) & $\begin{array}{c}195 \\
(86.66) \\
\end{array}$ & $\begin{array}{c}225 \\
(100) \\
\end{array}$ \\
\hline Upper middle & 25 (17.36) & $\begin{array}{c}119 \\
(82.63)\end{array}$ & $\begin{array}{c}144 \\
(100)\end{array}$ \\
\hline Middle & $51(16.88)$ & $\begin{array}{c}251 \\
(83.11)\end{array}$ & $\begin{array}{c}302 \\
(100) \\
\end{array}$ \\
\hline Lower middle & 17 (14.16) & $\begin{array}{c}103 \\
(85.83) \\
\end{array}$ & $\begin{array}{c}120 \\
(100)\end{array}$ \\
\hline Lower & $04(26.66)$ & $\begin{array}{c}11 \\
(73.33) \\
\end{array}$ & $15(100)$ \\
\hline Total & $127(15.73)$ & $\begin{array}{c}680 \\
(84.26)\end{array}$ & $\begin{array}{c}807 \\
(100)\end{array}$ \\
\hline
\end{tabular}

age group of $18-20$ years. By the age of 30 years, $4.7 \%$ of the study population had smoked cigarettes. The mean age of current smokers was 22.81 ( $(S D=3.51)$. This agewise variation in smoking came out to be statistically significant $(p=0.003)$.

Table 4 shows the association between socioeconomic status and smoking among the participants. It is observed from the above table that out of the 225 participants from the upper class, $13.33 \%$ were current smokers. In the upper-middle class, $17.36 \%$ were current smokers. The percentages of current smokers in the middle and lowermiddle classes were $16.88 \%$ and $14.16 \%$ respectively. 
Out of the 15 participants belonging to the lower class, $26.66 \%$ were current smokers. The association between socioeconomic status and smoking came out to be statistically significant $(p=0.002)$.

Table 5 shows the socio-environmental factors related to smoking in the study population. It was observed

Table 5.Socio-environmental Factors related to Smoking in the Study Population

\begin{tabular}{|c|c|c|c|}
\hline Predictors & $\begin{array}{c}\text { Yes } \\
\mathbf{n}(\%)\end{array}$ & $\begin{array}{c}\text { No } \\
\mathbf{n}(\%)\end{array}$ & $\begin{array}{c}\text { Don't Know } \\
\mathbf{n}(\%)\end{array}$ \\
\hline $\begin{array}{c}\text { Free availability } \\
\text { of tobacco } \\
\text { products }\end{array}$ & $\begin{array}{c}410 \\
(50.80)\end{array}$ & $\begin{array}{c}196 \\
(24.28)\end{array}$ & $201(24.90)$ \\
\hline $\begin{array}{c}\text { Indulgence } \\
\text { of friends in } \\
\text { smoking }\end{array}$ & $\begin{array}{c}214 \\
(26.51)\end{array}$ & $\begin{array}{c}517 \\
(64.06)\end{array}$ & $76(9.42)$ \\
\hline $\begin{array}{c}\text { Indulgence of } \\
\text { family members } \\
\text { in smoking }\end{array}$ & $86(10.65)$ & $\begin{array}{c}702 \\
(86.98)\end{array}$ & $19(2.3)$ \\
\hline $\begin{array}{c}\text { Influence } \\
\text { of tobacco } \\
\text { advertisement }\end{array}$ & $560(70)$ & $189(24)$ & $58(6)$ \\
\hline
\end{tabular}

Table 6.Reasons for starting Smoking among Current Smokers

$(\mathrm{N}=127)$

\begin{tabular}{|c|c|c|}
\hline $\begin{array}{c}\text { Reason for Starting } \\
\text { Smoking }\end{array}$ & Frequency & Percentage \\
\hline Stress & 82 & 64.6 \\
\hline Curiosity & 54 & 42.5 \\
\hline Role model & 46 & 36.22 \\
\hline Peer pressure & 44 & 34.4 \\
\hline Media & 22 & 17.2 \\
\hline Recreational purpose & 18 & 14.1 \\
\hline Misinformation & 08 & 6.3 \\
\hline $\begin{array}{c}\text { Presence of adults } \\
\text { smoking in the family }\end{array}$ & 07 & 5.5 \\
\hline Multiple responses & 36 & 28.34 \\
\hline
\end{tabular}

that $70 \%$ of the study subjects felt that tobacco-related advertisements influence tobacco consumption, $26.51 \%$ said that their friends indulged in smoking and $10.6 \%$ said that their family members were indulging in smoking. Half $(50.80 \%)$ of the study population felt that tobacco products were freely available to anyone without age restriction.

Table 6 depicts the reasons why current smokers had taken up this habit of smoking. It was observed that the main reason for starting smoking was stress $(64.6 \%)$, followed

\section{Table 7.Reasons for Initiation of Smoking} among Ever Smoker

\begin{tabular}{|c|c|c|}
\hline $\begin{array}{c}\text { Reason for Starting } \\
\text { Smoking }\end{array}$ & Frequency & Percentage \\
\hline Peer pressure & 30 & 78.9 \\
\hline Curiosity & 28 & 73.6 \\
\hline Role model & 24 & 63.15 \\
\hline Stress & 20 & 52.6 \\
\hline Media & 8 & 21.05 \\
\hline $\begin{array}{c}\text { Presence of adults } \\
\text { smoking in the } \\
\text { family }\end{array}$ & 6 & 15.7 \\
\hline $\begin{array}{c}\text { Misinformation } \\
\text { Recreational } \\
\text { purpose }\end{array}$ & 4 & 10.25 \\
\hline Multiple responses & 17 & 10.25 \\
\hline
\end{tabular}

by curiosity (42.5\%). $34.4 \%$ of the participants said that peer pressure was the reason for taking up smoking while $36.22 \%$ said that seeing their role model smoke was the main reason for starting smoking. $28.34 \%$ of respondents said there was more than one reason for taking up smoking, $17.2 \%$ started smoking because of media influence while $5.5 \%$ started smoking after seeing adults in the family.

Table 7 depicts the reasons for initiation of smoking among ever smokers. It was observed from our study that majority (78.9\%) of them started smoking because of peer pressure followed by $73.6 \%$ who tried smoking because of curiosity. $63.15 \%$ of the study subjects started smoking after seeing their role models smoke.

\section{Discussion}

Tobacco use, which is mainly cigarette smoking, is the principal factor behind avoidable morbidity and mortality globally. ${ }^{1}$ Smoking cessation is one of the most cost-effective steps in primary care. Majority of the research that has been done in this field to date was epidemiological in nature. Despite the clear evidence about the harmful effects of smoking, the overall self-reported prevalence of smoking was $20.4 \%$ and the prevalence of current smoking was found to be $15.73 \%$ which was in line with the WHO report on tobacco epidemic 2013 which showed the prevalence of current smoking to be $18 \% .^{2}$ According to the GATS 2009-2010 data. the overall prevalence of smoking was reported to be $24 \%$ and current smoking was found to be $14 \%$ among males, which was in consensus with our study. ${ }^{7}$ Another study done in Nepal by Chandrasekhar $\mathrm{TS}^{14}$ found the prevalence of current smoking to be $10.2 \%$ which was slightly less than our study. This difference might 
be because in his study females were also included who were excluded in our study.

There are many risk factors that aggravate a person to smoke, yet one of the most disturbing facts is that the age of initiation is continuously falling. ${ }^{15}$ Today, the age at which adolescents are taking up smoking is much less than that 10 years ago. This age group of $18-30$ years is a time of transition and many males are not able to handle the stress which could be because of academic stress or some other reason, which pushes them to take the help of cigarettes to reduce their stress levels. The current study also revealed that age was significantly associated with smoking and it was found that the number of current smokers increased with advancing age. Majority of the current smokers belonged to the age group of 27 to 30 years in this study.

The main reason behind the initiation of smoking was stress (64.6\%). This finding was not consistent with a study done by Philip $\mathrm{M}^{16}$ in 2014 in Kerala, which revealed that the main reason behind taking up smoking was peer pressure. It was also found in our study that the three main reasons for initiation were stress, curiosity and peer pressure which are in consensus with the study done by Ananda et al. ${ }^{17}$

A study conducted by Rosemary Hiscock et al. found that smoking was more prevalent among people belonging to the lower socioeconomic status which was in concordance with this study. ${ }^{18}$ This could have been due to poor education in this group of people.

\section{Conclusion}

The overall prevalence of smoking and the prevalence of current smoking was found to be in line with the WHO report on tobacco epidemic $2013 .^{2}$ Efforts should be continuously made to educate college students in their curriculum regarding the harmful effects of smoking.

The study also found that smoking was significantly higher in people with lower socioeconomic status. The prevalence of smoking increased with the advancement of age in this study. An important factor that led students to take up smoking was a high level of stress. Efforts should be made to decrease the stress level amongst college students, with the help of yoga and other exercises. Moreover, indirect advertisements of smoking, such as through media also played an important role. Efforts should be made in this regard to curb such influence through proper regulations so that the role models do not become a factor among people to initiate smoking.

\section{Source of Funding: None \\ Conflict of Interest: None \\ References}

1. Wallace RB, editor. Maxcy-Rosenau-Last. Public Health and Preventive Medicine. 15th ed. New York: The McGraw-Hill companies; 2008;6.

2. World Health Organization [Internet]. Global status report on noncommunicable diseases 2010; 2010 [cited 2021 May 5]. Available from: https://www.who.int/ $\mathrm{nmh} /$ publications/ncd_report_full_en.pdf

3. World Health Organization [Internet]. WHO Report on the Global Tobacco Epidemic, 2008: the MPOWER package; 2008 [cited 2021 May 5]. Available from: https://apps.who.int/iris/handle/10665/43818

4. World Health Organization [Internet]. Tobacco; 2019 [cited 2021 May 5]. Available from: https://www.who. int/health-topics/tobacco\#tab=tab_1

5. Jha P, Chaloupka FJ. Curbing the epidemic: governments and the economics of tobacco control. Washington DC: World Bank Publications; 1999. [Google Scholar]

6. US Department of Health and Human Services. A report of the Surgeon General: preventing tobacco use among young people. Washington DC: Department of Health and Human Services; 1994.

7. Ram F, Lahiri S, Parasuraman S, Singh LL, Paswan B, Singh SK, Das KC. Global Adult Tobacco Survey (GATS) India, 2009-2010. New Delhi: Ministry of Health and Family Welfare, Government of India; 2010.

8. Mathew DP, Indiradevi ER, Srijith R, Mathew T, Varghese $\mathrm{V}$, Vijayan V. Prevalence and risk factors for tobacco smoking among college students of South India. Int J Healthcare Sci. 2014;2(2):354-7.

9. US Department of Health and Human Services. Women and smoking: a report of the Surgeon General. Washington: US Government Printing Office (GPO); 2002 Aug 30;1-30.

10. Choudaha R [Internet]. Statistics on Indian higher education; 2013 [cited 2015 Sep 30]. Available from: http://www.dreducation.com/2013/08/data-statisticsindia-student-college.html

11. World Health Organization [Internet]. The Global Youth Tobacco Survey; 2020 [cited 2021 May 5]. Available from: https://apps.who.int/iris/bitstream/ handle/10665 /336752/WHO-EURO-2020-1513-4126356157-eng.pdf?sequence $=1$ \&isAllowed $=y$

12. Geckova AM, Stewart R, Dijk JP, Orosova OG, Groothoff JW, Post D. Influence of socio-economic status, parents and peers on smoking behavior of adolescents. Eur Addict Res. 2005;11(4):204-9. [PubMed] [Google Scholar]

13. Siziya S, Rudatsikira E, Muula AS, Ntata PR. Predictors of cigarette smoking among adolescents in rural Zambia: results from a cross sectional study from Chongwe district. Rural Remote Health. 2007;7(3):728. [PubMed] [Google Scholar]

14. Sreeramareddy CT, Kishore PV, Paudel J, Menezes RG. 
Prevalence and correlates of tobacco use amongst junior collegiate in twin cities of western Nepal: a crosssectional, questionnaire-based survey. BMC Public Health. 2008;8:97. [PubMed] [Google Scholar]

15. Gupta R, Gupta VP, Sarna M, Prakash H, Rastogi S, Gupta KD. Serial epidemiological surveys in an urban Indian population demonstrate increasing coronary risk factors among the lower socioeconomic strata. J Assoc Physicians India. 2003;51:470-7. [PubMed] [Google Scholar]

16. Ananda SR, Mythri H. Prevalence \& comparison of cigarette smoking habits among health care professional students. Indian J Res Pharma Biotech. 2014;2(4):136670.

17. Hiscock R, Bauld L, Amos A, Fidler JA, Munafò M. Socioeconomic status and smoking: a review. Ann NY Acad Sci. 2012;1248:107-23. [PubMed] [Google Scholar] 